\title{
Changing Cultural Landscapes under the Impact of Exile, Diasporas and Return Migration
}

\section{Paisajes culturales en cambio bajo el impacto del exilio, las diásporas y el retorno de la emigración}

\author{
Luis Roniger ${ }^{1}$ \\ Wake Forest University (Estados Unidos)
}

Recibido: 04-09-17

Aprobado: 09-10-17

\begin{abstract}
This article discusses the impact of territorial displacement on Argentina, Chile, Paraguay and Uruguay during the cycle of dictatorships and democratization of the late twentieth century and early twenty-first century. It points out the complexities and different forms of exile, expatriation and migration which these societies experienced, while asserting that exile could not be undone fully with democratization, as many of those who left did not come back, others left in new waves of expatriation, and even those who did return could not resume what had been left behind. Yet, the experience of living elsewhere broadened the social, political and cultural perspectives. Whether returning or not, or becoming sojourners, many individuals who left during the dictatorship made substantial contributions to the societies of origin in domains as varied as politics, arts and letter, science, the publishing industry, education, the state apparatus and the economy. Illustrations of such varied impact are presented.
\end{abstract}

Key-words: exile, migration, diaspora, transnational connections, cultural transformations.

\footnotetext{
${ }^{1}$ (ronigerl@wfu.edu). Luis Roniger es sociólogo político comparativo. Catedrático Reynolds de Estudios Latinoamericanos en Wake Forest University, ha publicado veinte libros, entre ellos Transnational Politics in Central America (University Press of Florida, 2011), La política del destierro y el exilio en América Latina (junto con Mario Sznajder, Fondo de Cultura Económica, 2013), Destierro y exilio en América Latina. Nuevos estudios y avances teóricos (EUDEBA, 2014). El Colegio de México publicará en breve su libro Historia mínima de los derechos humanos en América Latina (2018).
}

Araucaria. Revista Iberoamericana de Filosofia, Politica, Humanidades y Relaciones Internacionales, año 20, $\mathrm{n}^{\circ} 40$ Segundo semestre de 2018. Pp. 185-208. ISSN 1575-6823 e-ISSN 2340-2199 doi: 10.12795/araucaria.2018.i40.08 


\section{Resumen}

Este artículo discute el impacto del desplazamiento territorial en Argentina, Chile, Paraguay y Uruguay durante el ciclo de dictaduras y democratización de finales del siglo XX y principios del siglo XXI. Señala las complejidades y las diferentes formas de exilio, expatriación y migración que vivieron estas sociedades, al tiempo que afirma que el exilio no se pudo superar completamente con la democratización, ya que muchos de los que se marcharon no regresaron, otros se fueron en nuevas olas de expatriación, e incluso aquellos que regresaron no pudieron reanudar lo que se había dejado atrás. Sin embargo, la experiencia de vivir en otro lugar amplió las perspectivas sociales, políticas y culturales. Ya sea que regresaran o no, o mantuvieran una vida ambulante entre el país de origen y el país de residencia, muchos de aquéllos que dejaron el suelo patrio durante la dictadura hicieron en post-dictadura contribuciones sustanciales a las sociedades de origen en dominios tan variados como la política, las artes y las letras, la ciencia, la industria editorial, la educación, el aparato estatal y la economía. El artículo presenta ilustraciones de tal impacto variado en el Cono Sur.

Palabras-clave: exilio, migración, diáspora, conexiones transnacionales, transformaciones culturales.

In the introduction to Flexible Citizenship, published on the threshold of the new millennium, Aihwa Ong indicated that "the diasporan subject is now vested with the agency formerly sought in the working class and more recently in the subaltern subject". Ong was referring to the growing recognition that processes of transnational mobility acquired increasing global presence with observers seeing them as forces liberating individuals from "oppressive nationalism, repressive state structures and capitalism", while, at the same time, recognizing that nation-states continue to define, discipline and control all sorts of people, whether those in movement or in residence. ${ }^{2}$

In a recent book, Leonardo Senkman, Saúl Sosnowski, Mario Sznajder and I assess how the dynamics of transnational migrant displacements, diasporas and post-exilic relocations have affected Argentina, Chile, Paraguay, and Uruguay, embedding the national within transformative regional, transnational and global perspectives. Bringing together sociopolitical, cultural, and policy analysis with the testimonies of dozens of intellectuals, academics, political activists and policy makers, we address the impact of exilic and post-exilic relocations

${ }^{2}$ Aihwa Ong, Flexible Citizenship. The Cultural Logics of Transnationality. Durham and London: Duke University Press, 1999, p. 15. 
on people's lives and on their fractured experiences; the debates and prospects of return; the challenges of dis-exile and post-exilic trends; and the ways in which those who experienced territorial displacement impacted democratized institutions, public culture, and discourse. ${ }^{3}$ In this article I intend to bring attention to some of these transformations and their relevance for enabling new readings of recent history that emphasize the importance of regional, transnational, or global dimensions embedded in national outlooks. Specifically, I shall discuss some of the significance of those diasporic experiences and the impact of returnees on the culture, institutions and development of postauthoritarian politics in the Southern Cone of the Americas.

\section{The Impact and Multiple Character of Late Twentieth Century Displacement}

During the late twentieth century, dictatorships in Latin America hastened the outward movement of intellectuals, academics, artists, and political and social activists to other countries. Following the coups that toppled democratically elected governments or curtailed parliamentary oversight, the incoming military or civilian-military administrations assumed that, by forcing those aligned with opposition movements out of the country, they would assure their control of politics and domestic public spheres. Yet, by enlarging a diaspora of co-nationals, the authoritarian rulers merely extrapolated internal dissent and conflicts, emboldening opposition forces beyond their national borders.

Displaced individuals soon had a presence in many host countries, gaining the support of solidarity circles and advocacy networks that condemned authoritarianism and worked with exiles and internal resistance towards the restoration of electoral democracy. Exiles soon became vehicles for spreading cultural ideas from abroad, celebrating cosmopolitanism over nationalism, and emphasizing human rights and democracy in Latin American countries. Once return was possible, their experiences abroad could trigger processes of aggiornamento affecting the ways in which politics and other aspects of institutional and informal life were customarily conducted.

Let us start by inquiring about the terms used, as these affect our conceptualization of the issues at the center of this inquiry, noting that these are often superimposed on fuzzy real-life situations and multiple personal decisions and choices. The terms displacement and relocation are probably the most generic for addressing the phenomenon of exile and return. Territorial

\footnotetext{
${ }^{3}$ Luis Roniger, Leonardo Senkman, Saúl Ssosnowski and Mario Sznajder, Exile, Diaspora and Return: Changing Cultural Landscapes in Argentina, Chile, Paraguay and Uruguay. New York: Oxford University Press, 2018.
} 
displacement covers many life relocations, not just those of exiles, but also those of nomads, tourists, vagrants, guest workers and cosmopolitan travelers. In addition, there were many displacements conceived as migration or expatriation, i.e. a voluntary move, albeit also here the conditions leading to the 'exit' from a national territory may have been induced by an atmosphere of repression or structural constrains such as dismissal from a job and not just the personal drive to attain a better livelihood. In practice, it is often difficult to disentangle economic from political motivations within a community in the diaspora of co-nationals. In practice, much depends on how the newcomers claim their identities vis-à-vis each other, vis-à-vis the society of origin and vis-à-vis the society of destination, locations usually defined as the 'home' and 'host' societies, terms that can be problematized easily.

Forced migrants can be distinguished from voluntary migrants as well in terms of their time horizons, with the latter adopting mostly a future-oriented prospective look, whereas forced migrants such as exiles and refugees are more ambivalent towards the home country and defined by their dual (forward and backward) looking gaze. When the magnitude of displaced co-nationals becomes substantial, we tend to use the term exodus or massive exodus, as a simile. Starting in the late $20^{\text {th }}$ century, the phenomena of mass displacement and expatriation has been addressed by the international community, which has coined the legal term of refugee, usually perceived as being less Byronic and of lower socio-economic status than exiles. Calling attention to the legal status implies recognizing that some exiles left without documents or with just a laissez-passer issued by a host country, while others left legally or illegally (i.e. smuggled across borders), but with documentation that eased the process of their legalization abroad, even when in some cases the home state refused to renew the passport of exiled citizens.

In addition, the categories used are affected by the condition under which individuals arrived in the host countries. Some arrived with diplomatic asylum; others with a visa or with a refugee status issued by the UNCHR (ACNUR); still others as tourists, with a temporary permit, or even a labor contract. Moreover, the categories taken on by displaced individuals might change due to changes in their plans and because of the conditions that took them abroad. Thus, an exile could turn into a migrant once changes in government or the power structure took place and the impediments to a possible return to the home country were removed. Given such changes, there were migrants and exiles that started going back and forth between the host country of residence and the home country. We may define such individuals as sojourners. Conclusively, there was a huge variation in the ways in which diasporas emerged and developed strategies of survival and global engagement. ${ }^{4}$

${ }^{4}$ Alan Gamlen, "Creating and destroying diaspora strategies". Working Papers No. 31, April 
Of significance for our discussion is that this huge internal diversity, which is always present in diasporas of co-nationals, was mediated in periods of dictatorship, by the way in which political exiles could become the voice and image of a diaspora, stemming from the relative mix of political and economic motivations projected within a community of co-nationals. For instance, in the case of Central Americans since the 1970s, despite the clear background of generalized violence and repression motivating the massive flow of individuals escaping Guatemala and El Salvador, primarily to Mexico, collective representations were tinted with the image of refugees on the move. This image was further reinforced by realizing that many of them hoped to move further north to the USA in search of better sources of livelihood.

Contrastingly, the Chileans who fled to exile or were expelled from Chile turned into the pivotal core of a vibrant diaspora that further projected into global awareness the plight of their society undergoing massive human rights violations. Of course, those exiles came from a country with an articulated political system and political parties that found almost immediate resonance with sister-parties and intellectual circles both in the Western world and in Communist states, in Latin America, Europe and many distant lands. Yet, they were instrumental in proactively projecting themselves through networks of solidarity and advocacy and international organizations. The military takeover did constitute a breakdown of the Chilean constitutional tradition, and ended the first experiment of a Marxist-Socialist administration reaching power through the ballots. The brutality and magnitude of repression following the military takeover made Chile into the cause célèbre of both the Left and the liberal democratic forces. The Chilean military rulers closed the political sphere, alienating many Christian Democrats and members of other non-revolutionary and centrist parties, and creating a constellation of forces that transcended the East-West divide of the Cold War. Thus, the Chilean Diaspora involved a critical mass of politically pro-active exiles that endowed the fight against the military dictatorship with a strong moral claim, in addition to the Byronic, heroic image many of them proudly projected in exile. The projection of the Chilean counter-intelligence's activities to Latin America, the US and Europe, and the coordination of repression with other countries in the framework of Operation Condor led to the assassination of a few prominent exiles, ${ }^{5}$ but were ineffective in silencing an opposition whose voice gained resonance through the multiplier factor of transnational networks and international

2011; Mark Overmyer and Enrique Sepúlveda III, eds. Global Latin(o) Americanos. Transoceanic Diasporas and Regional Migrations. New York: Oxford University Press, 2018.

5 By the mid-1970s, the security services of Argentina, Bolivia, Brazil, Chile, Paraguay and Uruguay formalized their cooperation in Operation Condor, designed to coordinate the transnational repression against the opponents of the South American dictatorships and military governments. See J. Patrice McSherry, Predatory States. Lanham: Rowman and Littlefield, 2005; and John Dinges, The Condor Years. New York: The New Press, 2005. 
organizations. Pinochet would soon have to face the political implications of a war that had become transnational and that, despite Pinochet's claim of being at the forefront of the struggle against Communism, eventually led to a loss of support in Western democracies. By becoming a voice for the entire Diaspora, while being transformed by their global exposure, Chilean political exiles had a crucial impact on the internationalization of human rights and the struggle for the restoration of democracy in the home country. ${ }^{6}$

\section{Possible Returns}

The possibility of return is ensconced at the very moment of displacement. A first step is to differentiate between voluntary displacement and forced displacement. But, as I indicated, the distinction between these categories is not clear-cut, even if it can be elaborated for analytical purposes. Equally blurring are the many 'shades' of voluntary migration, which involve at least the following: permanent migration as distinguished from temporary migration; migration remaining in the site of relocation as distinguished from serial relocation; and also various forms of temporary migration, i.e. circulatory (e.g. 'migración golondrina'); transient (e.g. African and Asian migrants moving across South Europe on their way to Germany, Sweden or the UK); contract migration (e.g. such as that of guest workers from the Philippines into Israel, or Hong Kong); and the relocation of diplomats and expatriates. Also forced migration can be due to various motivations such as escaping persecution or fleeing from natural disasters. Also, as indicated above, varied may be their reception as exiles, refugees or asylum seekers.

We should thus keep in mind that distinguishing 'voluntary' from 'forced' migration is problematic, since usually there may be a combination of motivations and definitions in relocating spatially. Yet, for the purposes of characterization, let us draw the seeming contrast between forced migration as embodied by exiles and voluntary migration as embodied by economic migrants. In the case of migrants, the forward-looking perspective involves a drive to integrate into the new environment. This perspective does not obliterate nostalgia, although relegates return into an undefined future, provided the individual becomes integrated socially and culturally to her new environment. Still, we shall see this assumption is also problematic, as many return even and especially when they succeeded economically.

\footnotetext{
${ }^{6}$ Luis Roniger, 'Latinos' in Exile: Latin American Political Diasporas and their National and Transnational Struggle”, in Overmyer-Velázquez and Sepúlveda, Global Latin(o) Americanos (2018), pp. 231-254.
}

Araucaria. Revista Iberoamericana de Filosofía, Política, Humanidades y Relaciones Internacionales, año 20, $\mathrm{n}^{\circ} 40$. Segundo semestre de 2018. Pp. 185-208. ISSN 1575-6823 e-ISSN 2340-2199 doi: 10.12795/araucaria.2018.i40.08 
In the case of exiles, for many of them pining for home was a nostalgic dream inhabited by lost life projects, by social networks and by memories of childhood landscapes. The impaired yet persistent will to return can be considered one of the key traits defining exile as a distinctive category of displacement. Notwithstanding some of the opportunities that living abroad provides, exile is a traumatic experience that sometimes shapes a mindset idealizing return. Of course, once the conditions forcing migration out of the country of origin disappear, then the will to return is tested and in many cases, if staying abroad, the exiles must recognize they have become something else, i.e. migrants.

But even full-fledged voluntary migrants consider returning. In their case, the usual popular truism is that they come to stay in the country of destination. According to the popular view, the development gap between home and host countries (the more neutral terms are countries of origin and destination) is such, that the economic prospects and the possibility of accumulating human capital are thought as ensuring migrants will stay.

There are several sets of problematic assumptions here. Empirical studies show that return migration is substantial. There are plenty of studies showing this. For instance, for the USA between 1908-57, it was found that whereas 15.7 million immigrants arrived, almost a third (4.8 million) had left. Likewise, that about $1 / 3$ of legal immigrants to the USA re-emigrated in the 1960s and between $20-50 \%$ re-emigrated in the 1970 s - thus problematizing the economicist assumption of mainstream migration research (since we may suspect the impact of the Vietnam war and the military draft on some of those leaving). Also, that $85 \%$ of one million Greeks migrating to Germany between 1960-84 were found to have gone back by the late $1980 \mathrm{~s}$; that, at least $40 \%$ of those 25 -years and older who were in England one year after arrival had remained after 10 years, in some cases (non-whites), reaching only $20 \%$; that $40 \%$ of all males and $55 \%$ of all females had left after 5 years; and that return also takes place not just in a global North-Global South direction but also in a global South-global South direction, from Mali to Cote d'Ivoire, or other directions, as from Russia back to Armenia. So, there is varied data indicating how substantial is also return migration. ${ }^{7}$ On the other hand, only a minor portion of those who left their home countries during dictatorships in South America did return once those societies restored democracy in the late twentieth century. ${ }^{8}$

We should also follow why do exiles and migrants return. What are the theories that explain this phenomenon? Usually, the suggested models are political for the exiles and economic for the case of migrants. For instance,

\footnotetext{
${ }^{7}$ Data sources are omitted here for reasons of space, yet readers can find them easily online.

${ }^{8}$ For a quantitative assessment, see Roniger, Senkman, Sosnowski and Sznajder, Exile, Diaspora and Return: Changing Cultural Landscapes in Argentina, Chile, Paraguay and Uruguay. New York: Oxford University Press, 2018, pp. 99-138.
}

Araucaria. Revista Iberoamericana de Filosofia, Politica, Humanidades y Relaciones Internacionales, año 20, $\mathrm{n}^{\circ} 40$ Segundo semestre de 2018. Pp. 185-208. ISSN 1575-6823 e-ISSN 2340-2199 doi: 10.12795/araucaria.2018.i40.08 
the models of return migration advance claims such as the following: that the marginal utility of wage differentials, higher in the country of relocation, decreases with the passing of time; that there may be higher chances of maximizing the higher purchasing power once back in the home country; and/ or that the return on the increased human capital many gained while in the country of relocation is likely to be higher once back in the country of origin. Accordingly, there is often an assumption of calculated strategy and talk of optimal migration duration. Once the objectives of migration are achieved in the destination countries, the assumption usually is that the likelihood will increase of migrants returning to the country of origin. In the case of exiles, explanatory models look for changes in the legal and political environment as triggering return. Yet, in both cases, emotional and relational ties related to the length of time away and the changed life circumstances of the individual, also play a huge role on personal decisions.

Here transnationalism and theories addressing transnational and diaspora networks add important hindsight. For once, displaced individuals do not cut their ties with the home country resettling in other countries and neither with co-nationals and others in the diaspora once opting to return. The flow of remittances in the case of voluntary migrants and the commitment to a political banner in the case of exiles are good indicators of such ongoing attachments and continuous assessment of the will to retain an allegiance to a globally dispersed group (a Diaspora), to ethnic and kin relationships or a political movement back home. In other words, there is no disjunction between having relocated abroad and being connected back home, and vice versa, the equation of which will vary according to a myriad of personal and collective considerations 9 .

Fiction often captures these nuances. There is a movie that stresses the metamorphoses of self-definitions of individuals moving to a new environment and how problematic may be the decision to return to the place of origin or stay in the place of residence/relocation, once political or economic conditions enable a return. The film is "Made in Argentina," a film directed by Juan José Jusid, about an Argentinean couple exiled for many years in the US and returning following democratization for a visit for a family wedding. The couple is torn between a possible return to the home country and the thought of taking the wife's brother and his family to the US. Whereas Argentina pulled for the couple visiting from the USA a wide gamut of emotional chords - from nostalgic meetings with figures of the past and reliving one's youth to the remembrance of betrayals and rejections that led them to flee the country- prospects in the US are equally challenging. The attraction there is of

\footnotetext{
${ }^{9}$ See Judit Bokser Liwerant, "Being National, Being Transnational: Snapshots of Belonging and Citizenship", in Mario Sznajder, Luis Roniger and Carlos A. Forment, eds. Shifting Frontiers of Citizenship: The Latin American Experience. Leiden: Brill, 2013, pp. 342-365.
} 
a modern, dynamic and economically prosperous society, prevailing over the grim economic situation of their relatives in Argentina. And yet, they are fully aware that they are strangers in a foreign land and lack a home feeling. This push-pull does not lead to either return or emigration and each couple follows its own way. The principled point is that those who thought of themselves as exiles return to the US knowing that they have become migrants in the society where they resettled; and the relatives opt to stay despite the allure of a better economic future in the US environment. ${ }^{10}$

Depending on circumstances, return can be no less traumatic than leaving in the first place. Given the changes that took place with the passing of time in the country of origin, to return often means relocating to a setting now only partially known; a fact that transforms return into a new traumatic displacement, which in the case of Latin America was particularly felt as a new exile.

For once, societies at large were not always welcoming to returnees and their families. Discussions arose about the relative suffering of those who stayed vis-à-vis those who left. Likewise, disagreements existed on what state benefits returnees should receive, and whether these should be greater than those assigned to residents. The gap between those who remained in the country and those who left emerged with special virulence in Argentina, where the intellectual community was deeply fractured. But even when, as in Uruguay and Chile, there was less animosity between sectors that had lived through different life experiences at home and abroad, the governments stressed that their policies were not designed to privilege returnees. Given the length and magnitude of Paraguayan exile there was a sustained flow of exchanges between the diaspora and the home country; still, the rejection of those who returned from exile was far from an isolated instance, especially when set against a background of economic downturn and when potential and actual returnees belonged to opposite political forces.

Many pondered this sense of estrangement upon reuniting with their conationals. Hugo Achúgar's statement is perhaps paradigmatic:

Uruguayans of exile and dis-exile... we are beings [torn] between two waters, the marginals of yesterday and tomorrow... strangers ...both in exile and back... To return is, somehow, to state the obvious: 'the impossibility of returning home,' as Thomas Wolfe said... the mythical place was real in its potentiality. Once achieved, it becomes the place of encounter and disencounter. The picture is moved... back home, or at least with the illusion of having really come back home... we find that everything and everybody has changed: in the first place, we who left. We got the country back and we lost it. If the temporary marked part of our exile, what we had to live through upon returning was also frail, unsure, and transitory. We are in a process of dis-exile,

${ }_{10}$ "Made in Argentina" (also known as "Made in Lanús"), director: Juan J. Jusid, Argentina, 1987. 
because dis-exile is not achieved all at once and forever. Dis-exile is not a noisy, one-time performance. ...It is a lasting wound that may or may not heal. ${ }^{11}$

Writer Tununa Mercado once said that "the expatriate that finally returned...found the places perforated and lived through the vertigo of falling into those holes." 12 In the literature, one finds such allusions to return as a second exile, an inner exile in the eyes of some returnees. Perhaps the concept of post-exile best reflects what exile itself opened-up and cannot be turned back to a normal flow of life. It implies that return cannot undo completely the impact and scars of exile. An alternative term, 'dis-exile' (desexilio) was coined by writer Mario Benedetti decades ago to suggest the exile's protracted process of accommodation to 'undo exile.' 13

\section{Undoing Exile}

In Exile, Diaspora and Return, we trace how difficult is to undo exile. Exile's evils are numerous and difficult to redress. Forced displacement created problems that impacted not only the lives of individuals while abroad, but also created difficulties for those willing to return. While political changes may revert institutional exclusion and formally allow inclusion, the possibility of returning demanded not only administrative and material mechanisms to help the returnees, but also the exiles' ability to overcome the damages inflicted by institutionalized exclusion. In addition to closing open judicial processes against returnees, ${ }^{14}$ contemplating reparations, compensations, reintegration into the labor market, securing housing and entry into the educational system, there were many other subtle aspects to be addressed. The main difficulty lied in the fact that the exiles' lives deviated from what should have been their "normal course." Yet, with the transition to democracy and thereafter, many of those individuals had a substantive impact on the reconstitution of public life and institutions in the countries of origin, whether while staying in the countries of relocation or once some of them returned to the home country.

11 Hugo Achúgar, "Entre dos orillas, los puentes necesarios," in Saúl Sosnowski ed. Represión, exilio y democracia: La cultura uruguaya. College Park and Montevideo: University of Maryland and Ediciones de la Banda Oriental, 1987, pp. 242-43.

${ }_{12}$ Florinda Goldberg, "Latin American Migrant Writers: 'Nomadic, Decentered, Contrapuntal," in Luis Roniger and Carlos H Waisman, eds. Globality and Multiple Modernities. Sussex Academic Press, 2002, pp. 299-300. See also María Angélica Celedón and Luz María Opazo Volver a empezar. Santiago: Pehuén, 1987.

${ }_{13}^{13}$ Mario Benedetti, El desexilio y otras conjeturas. Buenos Aires: Nueva Imagen, 1985.

${ }^{14}$ This challenge was particularly acute in the case of re-democratized Argentina. See María Soledad Lastra, Volver del exilio. Historia comparada de las políticas de recepción en las posdictaduras de la Argentina y Uruguay (1983-1989). (Universidad Nacional de La Plata; Universidad Nacional de General Sarmiento; y Universidad Nacional de Misiones, 2016. 
Among such contributions one may note their political input, first during their exile and then upon democratization. As indicated, following massive displacement, diaspora communities became political loci where anti-dictatorial groups and fronts emerged, combining local support and transnational networks of solidarity with the input of a wide array of exile organizations leading campaigns and the struggle against repressive dictatorships in their home countries. Exile organizations provided much-needed information and political content, galvanizing international public opinion and gaining global resonance through wide-ranging activities. Through lectures, cultural events, publications, and film-making (as in the case of Chilean film director Miguel Littin, Argentine historian/film maker Osvaldo Bayer, Uruguayan composer/ singer Daniel Viglietti, Paraguayan writer Augusto Roa Bastos, among many others), exiles documented the situation in the home countries to circumvent censorship. A minority of exiles also organized clandestinely to return and continue their armed struggle.

Following democratic transitions, returnees were important actors once more. In this sense, Chile stands out due to the key influence exercised by returning politicians on the establishment of the Concertación de Partidos por la Democracia, the multi-party coalition launched in January 1988 that won that year's plebiscite, thus enabling the transition to democracy. Illustrative is the case of the PPD, the Partido por la Democracia, a Center-Left party founded by Ricardo Lagos in 1987 that served as an alternative framework of activism for many members of the Socialist Party, which remained illegal under Pinochet. The PPD came to prominence through its work in the campaign for the "No" vote leading to the 1988 plebiscite. Out of the party's nine presidentes during the period 1987-2011, seven had experienced exile; namely: Ricardo Lagos Escobar (1987-90); Erich Schnake Silva (1990-92); Sergio Bitar Chacra (1992-94; 1997-2000; 2006-08); Jorge Schaulsohn Brodsky (1994-97); Pepe Auth Stewart (2008-09); Adriana Muñoz D'Albora (2009-10); and Carolina Toha Morales (2010-12). Only two -Guido Girardi Lavín (2000-03) and Víctor Barueto (2003-06) - were not displaced during the dictatorship. The Concertación governed Chile from 1990 to 2010 and carried out the various constitutional reforms of 1989-2005, most aimed at eliminating the authoritarian enclaves and veto power of non-elected institutions which characterized the 1980 constitution. In 1989, 54 reforms of the 1980 Constitution were adopted through negotiations between the military and the opposition, and another 15 were enacted between 1990 and 2005. Many returning politicians served in the administrations of the Concertación, starting with Presidents Ricardo Lagos and Michelle Bachelet. Most significantly, an analysis of the cabinets for the period 1994-2009 indicates that the percentage of ministers that had experienced exile during the dictatorship was substantial. Although there were 
variations across the various administrations, the rate of cabinet members who had experienced exile remained high for the period that the Concertación held power, and led the reforms to Pinochet's constitution. ${ }^{15}$

Jaime Esponda, a long-term human-rights activist and later head of the Oficina Nacional del Retorno ${ }^{16}$, singled out the return of political leaders and intellectuals as crucial for the transition to democracy:

It is enough to think about the names: José Miguel Insulza, José Antonio Viera Gallo, Enrique Correa, Ricardo Lagos, Michelle Bachelet. Perhaps up to $90 \%$ of the political class of the Concertación was made up by exiles. The experience abroad was an enormous jump for them from every perspective; and their return enriched the country. They assimilated experiences that made possible a peaceful transition to democracy, with problems, yet great progress in the area of human rights. There was also a cultural change that took place in the politics of the Concertación. ...Chile was very disorderly; schedules were not kept; in the public administration, little work was done. Politics were rather populist, regardless of whether the Right or the Left was in power. There was enough demagoguery and a lack of professionalism.... I believe that the group that returned from exile implanted a different culture, one of discipline and greater precision in the public administration. It is true that we still need a modernization of the state, but this state functions after receiving an enormous plus from the returnees. If one looks for a central key to explain Chile's success, my thesis is that the large component of returnees has been critical to the success of the political transition and economic development of our country. Returnees played a key role as members of the government, fundamentally in the Executive branch, due to their ability, political maturity and their implanting a style of living, of cultural understandings [that they brought back from exile]." ${ }^{\prime 17}$

Some returnees contributed significantly to moving political circles closer to confronting the legacy of human rights violations shaped by Pinochet's repressive policies. Two prominent members of the National Commission of Truth and Reconciliation (the 'Rettig Commission'), charged by President Patricio Aylwin with investigating cases that resulted in death due to state and political violence, had experienced exile. Jaime Castillo Velasco, a Christian Democrat lawyer and former minister of the Frei administration, was expelled in 1976 -together with another activist, Eugenio Velasco Letelier- accused of having a dangerous impact on state security due to their critical stand on

15 Six out of thirteen ministerial posts were filled by former exiles in President Aylwin administration; seven out of 27 in Frei's administration; seven out of 24 in Lagos' administration; and 8 out of 22 in Bachellet's administration. Contrastingly, in President Piñera's initial cabinet only one minister, Jaime Ravinet de la Fuente, had been exiled.

${ }^{16}$ Functioning within the Ministry of Justice and reporting to the President, the ONR had a coordinating function between the Chilean government, international institutions, and NGOs in matters related to return from exile. It operated for about four years starting in 1990 .

${ }^{17}$ Interview with Jaime Esponda, Santiago, 18 August 2015. 
human rights violations. Once in Venezuela, he founded the Latin American Secretariat of Human Rights and was a severe critic of the abuse inherent in deportation and exile, claiming that living in one's home country is a basic right. Being allowed to return to Chile in 1978, he suffered a new exile in 1981, returning finally in 1983. Later, he became president of the Chilean Committee of Human Rights.

José Zalaquett Daher was the second member of the Rettig Commission who had experienced exile. As legal director of the Committee for Peace, that defended detainees of the military regime, he was imprisoned in November 1975 and months later left for exile. In London, he chaired the executive committee of Amnesty International from 1978 to 1982 . Upon returning to Chile, he had a fundamental role in the Rettig Commission and in the Peace Roundtable, a 'dialogue table' between the military and the civilian left that operated between August 1999 and June 2000. As director of the Centre for Human Rights of the Faculty of Law of the University of Chile, Zalaquett Daher continued to have a great impact on the recognition and institutionalization of a normative of human rights.

Contrastingly, in Paraguay returnees were less able to effect substantial political change, as seen in the persistent weight of the Colorado Party at the center of power following the end of Alfredo Stroessner's rule in 1989. Still, even in Paraguay returnees were important as harbingers of new ideas. For instance, Augusto Roa Bastos had a charismatic impact on the nation, and particularly on the young. Particularly after 1982, he led an anti-Stroessner campaign that culminated in a major international event in February 1987 in Madrid under the auspices of Spain's Socialist party (PSOE). About 40 personalities who represented varying political positions, some who lived in exile and others in Paraguay, were called by Roa Bastos, at a time when many feared a civil war or a blood bath, to advance democracy without resorting to violence. ${ }^{18}$

For many political and entrepreneurial elites, life abroad operated unprecedented changes in their training, education, and class positions. By upgrading their skills and opening to global trends, individuals who had been expelled, fled, or left to study abroad, upon returning, managed to advance both socially and institutionally. Illustrative of life changing circumstances involved in settling abroad are the cases of Enrique Kohn and Félix Kaufman, nationals of Chile and Argentina, respectively, who moved abroad following the onset of dictatorship in their home countries. Kohn relocated to Israel and then Ecuador. Tired of waiting for re-democratization, he used his former network of friends in the home country to return before the end of Pinochet's rule. With

\footnotetext{
${ }^{18}$ In reaction, the dictatorship revoked Roa Bastos' citizenship, but then the writer received an honorary Spanish citizenship in 1983 as well as French citizenship in 1987.
} 
the knowledge that he acquired in the countries of relocation, once back he successfully launched a construction company in Chile. ${ }^{19}$ Félix Kaufman had spent one year in prison in Argentina in 1968-69 for political agitation and was imprisoned for a second time in 1974. After four years in prison, he was given the option of leaving if he renounced his citizenship. He then moved to Israel and soon after relocated to France. In Paris, he worked in a printing plant for five years and became a militant in the French Trotskyist Party. His expulsion from Argentina had generated a psychological burden that in his words 'could only be undone by returning'. Upon his return, Kaufman ceased to be politically active and felt disconnected from old comrades who were not sent to prison and did not go into exile. With his experience and studies in economics, he began a new career as a sales manager and then established a consulting firm..$^{20}$ The experiences of these two exiles may be unique in the details, but are representative of thousands of individuals whose varied experience abroad widened their life chances and who decided to return on their own based on multiple contingent factors.

Returning intellectuals made major contributions to the reconstitution of many domains. A short list would include the publishing industry, with returnees such as Daniel Divinsky in Argentina, Carlos Orellana in Chile, Juan Bautista Rivarola Matto in Paraguay and Pablo Harari in Uruguay, who took on many initiatives, supporting the publication of books reflecting the experience under the dictatorship and the challenges of re-democratization. Illustrative is the case of Divinsky. Trained as a lawyer, Divinsky (1942-) had founded in 1967 Ediciones de la Flor, which published for the first-time texts by Rodolfo Walsh and Mafalda, Quino's world famous and influential comic strip. It was followed by, among other publications, books by humorists and social critics such as Fontanarrosa, Caloi, Liniers, Sendra and Maitena, that became wellknown after publishing for the first time in Ediciones de la Flor. In 1976, with the onset of the military government, jailed for four months, Divinsky, his partner and then wife, Kuky Miller, and little son, left for Venezuela, after being freed thanks to an international campaign led by publishers and editors from other countries. ${ }^{21}$ While in exile, Divinsky continued his association with the publishing industry. He worked closely with Ángel Rama, the Uruguayan cultural critic who conceived of and directed "Biblioteca Ayacucho." Funded by the Venezuelan government, its goal was to publish 500 volumes that a team of specialists considered the major works to understand Latin American culture. His links with Venezuelan journalism and culture continued after his

\footnotetext{
19 Interview by Mario Sznajder with Enrique Kohn, Santiago, 11 October 2011.

20 Interview by Mario Sznajder with Félix Kaufman, Buenos Aires, 28 September 2011.

${ }^{21}$ Divinsky was not a political activist and his detention was possibly due to having published a children's book whose cover page showed the rise of a fighting fist (the book carried the title Cinco dedos, five fingers).
} 
return to Argentina, and for many years Divinsky remained the editor of the cultural section of El Diario de Caracas. In 1982 Divinsky returned home and was active in Alfonsín's campaign. After Alfonsín's election, he headed a major radio station, LR3 Radio Belgrano, and directed Plural, a magazine published by the Fundación Plural para la Participación Democrática, in which both Radical Party members and independents supported the democratic transition. While continuing to head Ediciones de la Flor, he published articles in the newspaper Página/12 and held high-ranking positions in the Argentine Chamber of Publishers. ${ }^{22}$ One testimony to his impact on public culture is that, as head of LR3 Radio Belgrano, Divinsky offered returnee Horacio Salas (1938-), a journalist and writer that had been exiled in Spain from 1976 to 1982 , a space of 4 daily hours. Salas launched a very popular program of Latin American music, poetry and interviews, "Dar la nota," that ran for six years (1985-89), interviewing close to 700 arts and letters personalities from Argentina and other Latin American countries. ${ }^{23}$ Later, Salas became Secretary of Culture of Buenos Aires, member of the board of directors of the Fondo Nacional de las Artes, and director of the National Library.

Even in Paraguay, a society with dominant oral traditions and more reduced circles of readers of books, a returnee, journalist and novelist Juan Bautista Rivarola Matto (1933-1991), attempted, although with partial success, to make a significant change by launching a publishing house in the early 1980s, when Paraguay was still under Stroessner's rule. Rivarola Matto spent two decades in exile, returning in 1979; he then founded Editorial Napa together with Alvaro Ayala. Conceiving the idea of popular distribution of valuable books, they launched the initiative of the 'Paraguayan book of the month,' producing 42 titles between 1980 and 1984. Among the books were a bilingual, GuaraníSpanish edition of popular Paraguayan tales and the memoirs of Colonel Arturo Bray, presenting critical portrayals of key historical personalities which provided a revisionist reading of official narrative. Nonetheless, Napa had to close due to the combined impact of a limited internal market and the closure of Paraguay to external book markets.

Returnees such as Mempo Giardinelli in Argentina and Ricardo Ehrlich in Uruguay, each from very different platforms, positions and scope, were key players in efforts to eradicate illiteracy and contribute to major initiatives to raise the standards of both informal and formal education. After gaining recognition as a writer during his exile in Mexico, Mempo Giardinelli (1947- ) returned to Argentina in 1983, the year Mexico's Instituto Nacional de Bellas Artes awarded him the National Prize for his novel

22 Interview by Leonardo Senkman with Daniel Divinsky, in Buenos Aires, 22 December 2011.

23 Interview by Dr. Ricardo Dealecsandris with Horacio Salas, in the TV program "Dialogando" (www.c21tv.com.ar), July 2010; accessed 28 July 2013. 
Luna caliente, the first to a non-Mexican. Two years after his return, one of Giardinelli's first initiatives was to launch in his hometown Resistencia in the province of Chaco, the magazine Puro Cuento (1986-1992), modeled on Edmundo Valadés's long running Mexican publication El cuento. It served as a forum where cultural voices stemming from the interior of Argentina could be heard and leave out anti-democratic, authoritarian and xenophobic positions:

\begin{abstract}
We decided not to dispute cultural power [...but rather to] take care of the entire country trying to move literature beyond Buenos Aires (desporteñizar), with an eye not on the fad of Latin-Americanism but rather striving to embrace a universalism supported by the demand for quality [...] by looking inside the country [...]. We are prepared to listen to all voices [...] We preserve that commitment from the territorial marginality we chose, but to which we somehow were condemned..$^{24}$
\end{abstract}

The economic crisis of the late 1980s and early 1990s led Giardinelli to move from publishing a literary magazine to creating "Fundación Mempo Giardinelli," geared to both academic and massive cultural dissemination. In 1991 Puro cuento conducted the first national survey of reading habits, and in 1996 a group of volunteers organized the first international forum to promote reading, which three years later became a core objective of the Foundation on a year-long basis. Since 1999, the Foundation has been promoting education with a humanistic orientation. It has a Center of High Literary and Social Studies, which manages cultural programs such as workshops, courses, conferences and exhibitions, and supports an exchange program with academics and students from U.S. universities and colleges. In 2001, it started enrichment courses for teachers and for the public at large aimed at widening reading practices and skills in the hinterland of provinces such as Chaco, Corrientes, Santa Fe and Misiones. It conducts a workshop on Argentine literature and criticism, ${ }^{25}$ as well as the innovative project Abuelas cuentacuentos, in which grandmothers read stories to children, thus creating a trans-generational emotional motivation among the young to engage in reading. ${ }^{26}$ Starting in July 2002, and due to the 2001 economic crisis, it also provided basic nutrition for children in poor neighborhoods. ${ }^{27}$

Uruguayan Ricardo Ehrlich (1948- ) had connections with the Tupamaros and was imprisoned and tortured. Released in 1973, he left for Argentina and after a short period he settled in Strasbourg, France, where he earned his Master

\footnotetext{
${ }^{24}$ Puro Cuento, 12 (1988): 1-2, in Aixa Valentina Natalini, "La minificción en Puro cuento (19861992)," Badebec Revista del Centro de Estudios de Teoría y Crítica Literaria. http://www.badebec. org/pdf/Aixa\%20Valentina\%20Natalini.pdf (accessed 23 July 2013).

${ }_{25}$ See http://seminariochaco.blogspot.com.ar/

26 Ver http://sws.eclac.cl/wb/default.asp?boardid=Promocion-Lectura\&style=WebBoard

27 See the site de la Fundación Giardinelli, http://www.fundamgiardinelli.org.ar/
} 
degree in Sciences from the University Louis Pasteur. In 1979 he earned a PhD in Physics. Upon returning to Uruguay in 1987, Ehrlich started cooperating with Omar Trujillo - who did not go into exile - and together they consolidated the newly created Faculty of Sciences at UDELAR, bringing the number of life scientists, such as chemists and molecular biologists from 4-5 to close to one hundred. As we interviewed him in April 2011 -in his position as Minister of Education - , he reflected on how the impact of the returnees was mediated by their ability to create bridges with those who had stayed:

I participated in the reconstruction of the scientific environment, where there was a very fruitful articulation, albeit not free from conflict, between insiles and exiles, an articulation that enabled to rebuild the educational system. The input of the exiles was fundamental... The main point of wisdom was to benefit from the plurality of approaches that people brought back from various parts of the globe. People expressed very different opinions, as they had very different experiences. There were some who maintained open spaces during the dictatorship; we also had to find articulations with them. The success or failure of many [scientific] projects depended on wise or unwise decisions on how to build such initial bridges. ${ }^{28}$

Ehrlich oversaw the creation of a biochemistry and molecular biology lab that achieved high academic standing and he also incorporated a significant number of young researchers to the Faculty. Ehrlich would be appointed director of UDELAR's Institute of Biology, in which he developed the first Master's program in biotechnology, a degree connected with industry that brought together a multi-disciplinary faculty. During this same period, he became a founding member of the Programa de Desarrollo de las Ciencias Básicas (PEDECIBA) and presided over the Comisión Sectorial de Investigación Cientifica (CSIC) charged with promoting academic research. In 1997, he was elected Dean of the Faculty of Sciences, a position he held until February of $2005 .^{29}$

In May 2005, as the Frente Amplio's candidate, Ehrlich was elected mayor of Montevideo with a $60.7 \%$ of the vote, defeating the son of former President Bordaberry of the Colorado Party. In 2010 Ehrlich was appointed Minister of Education under President Mujica. As minister, he developed an education plan, primarily addressing the achievement gap between students of different household incomes and the disparity in the quality of schools between Montevideo and the rest of the country. In cooperation with UDELAR and other institutions, he implemented a scholarship fund for underprivileged students. Ehrlich was particularly concerned that upon becoming minister, 25\%

\footnotetext{
${ }^{28}$ Interview with Ricardo Ehlich, Minister of Education, Montevideo, 26 April 2011.

29 "Intendente Municipal de Montevideo." Montevideo de Todos, in http://www.montevideo.gub. uy/institucional/gobierno/equipo-de-gobierno/intendente-municipal-de-montevideo-ricardo-ehrlich
} 
of Uruguayan youth between the ages of 17 and 25, were neither working nor studying. He demanded increased government accountability and called for the creation of a National Institute of Educational Evaluation to monitor progress. In higher education, Ehrlich promoted an initiative which would decentralize UDELAR and create three additional branches in the East, Northeast, and Northwest of the country. ${ }^{30}$

There were many other key individuals who upon their return from exile, functioned as leading figures in the reconstruction, modernization and expansion of higher education. Due to its reinsertion policies, this was particularly salient in Uruguay's case where three of the four provosts of the leading institution of higher learning, the Universidad de la República (UDELAR), were former exiles: professors Samuel Lichtensztejn (1934-2018), Rafael Guarga (1940- ) and Rodrigo Arocena (1947- ). This was also the case in Argentina and Chile, though within specific faculties and departments.

There were also significant impacts on the reformulation of the cannon of established disciplines, as in the case of literature with systematic critical readings offered by Noé Jitrik (1929- ) for Argentina and the proposals advanced by Augusto Roa Bastos (1917-2005) for Paraguay. Jitrik, a university professor, writer and poet, experienced exile for years, first in France and then in Mexico, because of two different military takeovers. Following democratization in 1983, Jitrik kept his Mexican position and was a 'sojourner' until he decided to settle back in Argentina. He had developed emotional ties with Mexico, had a son living there, and continued cooperating with a series of academic publications and initiatives. In 1996 UBA appointed him Emeritus Professor as he continued to lead the Institute of Latin American Literature. In 2001 the University of Puebla in Mexico awarded him the title of Doctor Honoris Causa. His intellectual trajectory and transnational experience led him, from 1999 to 2005, to direct and edit the 12-volume Historia critica de la literatura argentina. Through 250 essays, this collective work offered a global perspective on Argentine literature and restructured its cannon by including authors from the diaspora and issues that had been previously marginalized. Likewise, once able to go back and forth after 1989, after an exile of over forty years, Roa Bastos made what were considered useful comments on the 1992 Constitution. Settling back definitely in 1996, Roa Bastos focused all his energies trying to promote a change of mind of Paraguayans, that were emerging from what he defined as 'a century of destruction,' both driven externally by foreign powers and internally, by powerholders and elites that stifled any sign of autonomy and critical thinking.

30 "Ministro de Educación y Cultura." www.frenteamplio.org.uy/node/5718 Readers will find additional information on these and other initiatives in Chapter 7, of Exile, Diaspora and Return (2018), where we address the institutional imprint of return. 
In film, art, music and theater, the impact of returnees has been fundamental, especially when creators and performers returned to their home countries. Some, like Chilean directors Patricio Guzmán, Raúl Ruiz (a sojourner) and Miguel Littín created films that contributed critical perspectives on both pre-dictatorial politics and the legacy of dictatorship, thus moving public opinion beyond past dichotomies. Guzmán's documentary, Chile: La memoria obstinada (1997), provided a glimpse of times past to the new generations while bringing many to realize how change affected them and contemporary society. In the last months of Allende's government, Guzmán had collected filmed materials for what turned out to be La batalla de Chile, la lucha de un pueblo sin armas. Shown only once in his country, Guzmán was already in exile when the materials were smuggled out of Chile. Screened as a trilogy -La insurrección de la burguesía in 1975, El golpe de Estado in 1976, and El poder popular in 1979- the film director showed it following democratization to the younger generations, triggering at times a first encounter with unknown facts and polarized visions of the past. The result of this experiment in collective memory served as the basis for La memoria obstinada. ${ }^{31}$ Likewise, in Argentina, once back, journalist, political activist and writer Miguel Bonasso (1940- ), author of Recuerdo de la muerte, and Fernando Pino Solanas (1936- ), the film director of Tangos. El exilio de Gardel, one of the key films of the transition, continued to be active in their respective fields while also joining electoral politics. These few cases are representative of a much wider universe of individuals who impacted the public life and politics of the countries of origin, following the transitions and end of dictatorships which opened the road of return.

\section{The growing relevance of diaspora and transnational connections}

The post-dictatorial era witnessed new complex territorial displacements and migrations. Since return was only partially realized by the individuals who had been displaced for political reasons, and many others left without any intention to return, the presence of Diaspora communities turned into a permanent trait that added complexity to retaining a national identity in an era of transnational migration and de-territorialization. The return of exiles and expatriates was soon followed by the migration of others to countries such as the U.S., Spain or Italy in the 1980s-2000s. Research also had to address, albeit partially, this unique phenomenon of migration by descendants of early waves of immigrants moving "back" to the countries of their ancestors, primarily

${ }^{31}$ María Eugenia Horvitz Vásquez, "Entre la memoria y el cine: Re-visitando la historia reciente de Chile," in Julián Chaves Palacios, ed. La larga memoria de la dictadura en Iberoamérica: Argentina, Chile y España. Buenos Aires: Prometeo - AECID, 2010, pp. 75-112. 
in Europe ${ }^{32}$ From the perspective of the receiving countries and the official request by those leaving the Southern Cone, these individuals were returnees. The arrival of thousands of those migrants to countries such as Spain forced the expatriate intellectuals of the former wave -those who fled as exiles in earlier decades- to redefine their voice within the larger diaspora of co-nationals.

Finally, we note that there has been a third process with growing relevance to the opening of these countries to the global arena. Marked by an increasing movement of individuals studying abroad, professional considerations forced many to decide whether to return to the home country or stay abroad. From an academic perspective, the awareness shaped by years or decades of exile seems to have trickled down through the initiative of returnees and others into adopting substantive reforms at both universities and research institutions. Accordingly, beyond the specificity of each wave of territorial displacement and exposure to experiences abroad, taken together, all these phenomena reveal the opening of these countries to transnational life trajectories. We thus recognize the new transnational openings without following hasty forecasts of a post-national stage in which the issue of diaspora life loses theoretical relevance. ${ }^{33}$

In the case of the Southern Cone societies, we have analyzed the process of such transformation and refer to diaspora as an umbrella category describing very varied transnational communities that, while dispersed, recognize a substantial connection to their place of origin. We use the term with two denotations. Overall, by diaspora we refer to the diverse universe of conationals relocated abroad who still retained an emotional - and often political bond - with the home country and among various communities of co-nationals worldwide. Internally diverse, these communities included individuals who fled or were deported; individuals who left with their passports and others who smuggled themselves across borders or took refuge in embassies; individuals who saw themselves as exiles, expatriates or migrants, students, tourists and diplomats; individuals who sought to be recognized as refugees in need of asylum and those who refused adamantly to accede to such an international

32 Silvina Jensen, La huida del horror no fue olvido. El exilio político argentino en Cataluña (1976-1983). Barcelona, Bosch-CO.SO.FAM, 1998, pp.300-302; Adela Pellegrino, Migration from Latin America to Europe: Trends and Policy Challenges, Geneve: IOM, 2004; Juan Carlos Checa Olmos, and Ángeles Arjona Garrido, "Análisis comparativo de las migraciones de retorno desde Bélgica y Argentina hacia Andalucía (España)."”' Estudios Migratorios Latinoamericanos, 56 (2005): 65-95; Javier Grossutti Javier, "De Argentina al Friuli, Italia (1989-1994); Un caso de migración de retorno?" Estudios migratorios latinoamericanos, 56 (2005): 97-121; José María Serrano Martínez, "Extranjeros en España: residentes e inmigrantes. Situación presente y perspectivas inmediatas" Anales de historia contemporánea (Universidad de Murcia), 22 (2006): 38-42.

${ }^{33}$ Such is for instance the argument of Alfonso de Toro, stressing transculturality and hybiridity as the basic trait of humankind in our times. See "Pasajes, heterotopías, transculturalidad: estrategias de hibridación en las literaturas latinoamericanas" in Erna Pfeiffer, ed., Aves de paso. Autores latinoamericanos entre exilio y transculturación. 1970-2002. Madrid, Iberoamericana: Vervuert, 2005, pp.19-28

Araucaria. Revista Iberoamericana de Filosofía, Política, Humanidades y Relaciones Internacionales, año 20, $\mathrm{n}^{\circ} 40$. Segundo semestre de 2018. Pp. 185-208. ISSN 1575-6823 e-ISSN 2340-2199 doi: 10.12795/araucaria.2018.i40.08 
status. The common denominator was their mutual recognition as being nationals of the country of origin and parts of communities of co-nationals, some of whom had lost their political entitlements resulting from the policies of the home dictatorships. The internal diversity of each community and the multiplicity of sites of relocation created varied dynamics of reconstruction of identities, shifts in political projects and cultural transformations, with exiles being sometimes more salient in representing the diasporic communities and claiming a national voice even when detached from exercising their rights as citizens, and in other cases fading or failing to attain a protagonist role vis-à-vis migrants and other co-nationals.

In addition, we should address the diaspora of knowledge, i.e. the worldwide network of academics, professionals and entrepreneurs. Conceptually, in this sense, diaspora captures the idea that civil society is on the move; that nationstates are no longer the sole frame of reference for creating socio-cultural identities; and that globalization implies that identities largely depend upon how the relationships between these relocating individuals and their country of origin are defined, maintained, activated and reproduced over time, using among other things new information and communication technologies. Those connections imply that members of a diaspora not only embody skills and expertise but may also be network-builders. They are plunged into a rich scientific and technical environment in their host countries and in principle can draw upon such resources for future problem solving in the South. The inner differentiation may be immense and although individually they may constitute parts of epistemic communities, there is no claim on our part that they fulfill a unique transfer function, but rather that there has been interest both on their part and on the part of the home governments to launch policies of reconnection that can be mutually beneficial. ${ }^{34}$

\section{Conclusion}

The last waves of exile, expatriation and migration have generated new awareness to the lack of convergence between national identities and the territorial boundaries of the nation-state. Political exile and expatriation called into question the territorially bounded conception of the nation-states in South America, creating awareness to the inner tensions of that model. Exile implied a government's rupture of political obligations toward its citizens. Such actions, beyond generating a possible crisis in individual life projects of those who

\footnotetext{
${ }^{34}$ Gabriela Tejada, "Conocimiento y cooperación: Las diásporas científicas como agentes de desarrollo." Migración y desarrollo, 10, 18 (2012): 67-100. See also Yevgeny Kuznetzov, ed. Diaspora Networks and the International Migration of Skills. How Countries can draw on their Talent Abroad. Washington DC: World Bank Development Studies, 2006.
}

Araucaria. Revista Iberoamericana de Filosofia, Política, Humanidades y Relaciones Internacionales, año 20, $\mathrm{n}^{\circ} 40$ Segundo semestre de 2018. Pp. 185-208. ISSN 1575-6823 e-ISSN 2340-2199 doi: 10.12795/araucaria.2018.i40.08 
were expelled or forced to escape, opened a collective scenario for redefining national loyalties regardless of the loss of citizenship entitlements and political obligations to the home state and government. Many of those individuals had prior social and cultural capital and underwent many personal and organizational changes as they adjusted to the various cultural, linguistic, social and political landscapes of host countries. Moreover, that experience of de-territorialization implied coming to grips with their inability to achieve the political projects they had envisioned. The defeat forced them to reevaluate ideological prisms, while being abroad often prompted new understandings of world politics and cultural trends and, at the same time, to question previously held premises and markers of certainty. The activism of some of those exiles implied an ongoing relationship with the home country, itself a key factor when analyzing the experiences of returnees, sojourners and expatriates in the diaspora. It also implied the emergence of solidarity and transnational connections with citizens displaced from other Latin American countries, discovering common challenges and finding a new voice fighting for democracy and human rights. Last, but not least, while they faced personal and collective hardships, being abroad also provided many of these individuals with windows of opportunity for academic training, social growth and intellectual diversification, as well as organizational and cultural connections that individuals and organizations maintained and applied expanding the reach of their networks and interactions beyond state borders.

Argentina, Chile, Paraguay and Uruguay have undergone radical shifts by recognizing the importance of co-nationals in the diaspora, more recently the diaspora of scientists, academics and professionals, whose willingness to support joint ventures and initiatives has been sought after by the home countries. We may also note that these countries have increasingly debated, and in some cases, already moved into recognizing the rights of co-nationals in the diaspora to vote in national elections while remaining abroad. Although this development is not privative of the Southern Cone and can be found in such disparate cases as Mexico, Italy or Lebanon, in this case there is a direct link between forced massive migration and exile and the rise of awareness of the importance and gains to accrue by reconnecting and networking with co-nationals worldwide. We live in a world in which migrations, refugees, mobility, globalization and networks have become very important, and even a defining feature of these times. The lessons of massive exilic and post-exilic experiences of South America are likely to be of universal interest. 


\section{Referencias bibliográficas:}

Achúgar, Hugo, "Entre dos orillas, los puentes necesarios," in Saúl Sosnowski ed. Represión, exilio y democracia: La cultura uruguaya. College Park and Montevideo: University of Maryland and Ediciones de la Banda Oriental, 1987.

Benedetti, Mario, El desexilio y otras conjeturas. Buenos Aires: Nueva Imagen, 1985.

Bokser Liwerant, Judit, "Being National, Being Transnational: Snapshots of Belonging and Citizenship", in Mario Sznajder, Luis Roniger and Carlos

A. Forment, eds. Shifting Frontiers of Citizenship: The Latin American Experience. Leiden: Brill, 2013, pp. 342-365.

Celedón, María Angélica and Luz María Opazo Volver a empezar. Santiago: Pehuén, 1987.

Checa Olmos, Juan Carlos and Ángeles Arjona Garrido, “Análisis comparativo de las migraciones de retorno desde Bélgica y Argentina hacia Andalucía (España)." Estudios Migratorios Latinoamericanos, 56 (2005): 65-95.

Dinges, John, The Condor Years. New York: The New Press, 2005.

Gamlen, Alan, "Creating and destroying diaspora strategies". Working Papers No. 31, Abril de 2011.

Goldberg, Florinda, "Latin American Migrant Writers: 'Nomadic, Decentered, Contrapuntal," in Luis Roniger and Carlos H Waisman, eds. Globality and Multiple Modernities. Sussex Academic Press, 2002, pp. 285-312.

Grossutti, Javier, "De Argentina al Friuli, Italia (1989-1994); Un caso de migración de retorno?" Estudios migratorios latinoamericanos, 56 (2005): 97-121.

Horvitz Vásquez, María Eugenia, "Entre la memoria y el cine: Revisitando la historia reciente de Chile," in Julián Chaves Palacios, ed. La larga memoria de la dictadura en Iberoamérica: Argentina, Chile y España. Buenos Aires: Prometeo - AECID, 2010, pp. 75-112.

Jusid, Juan J., "Made in Argentina" (also known as 'Made in Lanús"), director: Argentina, 1987.

Jensen, Silvina, La huida del horror no fue olvido. El exilio político argentino en Cataluña (1976-1983). Barcelona, Bosch-CO.SO.FAM, 1998, pp.300302 ;

Kuznetzov, Yevgeny, ed. Diaspora Networks and the International Migration of Skills. How Countries can draw on their Talent Abroad. Washington DC: World Bank Development Studies, 2006. 
Lastra, María Soledad, Volver del exilio. Historia comparada de las políticas de recepción en las posdictaduras de la Argentina y Uruguay (1983-1989). (Universidad Nacional de La Plata; Universidad Nacional de General Sarmiento; y Universidad Nacional de Misiones, 2016.

McSherry, J. Patrice, Predatory States. Lanham: Rowman and Littlefield, 2005. Natalini, Aixa Valentina "La minificción en Puro cuento (1986-1992)," Badebec Revista del Centro de Estudios de Teoría y Crítica Literaria, in http:// www.badebec.org/pdf/Aixa\%20Valentina\%20Natalini.pdf (accessed 23 July 2013).

Ong, Aihwa Flexible Citizenship. The Cultural Logics of Transnationality. Durham and London: Duke University Press, 1999.

Overmyer, Mark and Enrique Sepúlveda III, eds. Global Latin(o) Americanos. Transoceanic Diasporas and Regional Migrations. New York: Oxford University Press, 2018.

Pellegrino, Adela, Migration from Latin America to Europe: Trends and Policy Challenges, Geneve: IOM, 2004.

Roniger, Luis, 'Latinos' in Exile: Latin American Political Diasporas and their National and Transnational Struggle", in Overmyer-Velázquez and Sepúlveda, Global Latin(o) Americanos (2018), pp. 231-254.

Roniger, Luis Leonardo Senkman, Saúl Ssosnowski and Mario Sznajder, Exile, Diaspora and Return: Changing Cultural Landscapes in Argentina, Chile, Paraguay and Uruguay. New York: Oxford University Press, 2018.

Serrano Martínez, José María, "Extranjeros en España: residentes e inmigrantes. Situación presente y perspectivas inmediatas."." Anales de historia contemporánea (Universidad de Murcia), 22 (2006): 38-42.

Tejada, Gabriela, "Conocimiento y cooperación: Las diásporas científicas como agentes de desarrollo." Migración y desarrollo, 10, 18 (2012): 67-100.

Toro, Alfonso de, "Pasajes, heterotopías, transculturalidad: estrategias de hibridación en las literaturas latinoamericanas" in Erna Pfeiffer, ed., Aves de paso. Autores latinoamericanos entre exilio y transculturación. 19702002. Madrid, Iberoamericana: Vervuert, 2005, pp. 19-28. 